\title{
The Construction of Inclusion and Inclusive Teaching by Physical Education Teachers
}

\author{
Caly Setiawan \\ Department of Physical Education, \\ Health, and Recreation \\ Universitas Negeri Yogyakarta \\ Yogyakarta, Indonesia \\ csetiawan@uny.ac.id
}

\author{
Muhammad Hamid Anwar \\ Department of Physical Education, \\ Health, and Recreation \\ Universitas Negeri Yogyakarta \\ Yogyakarta, Indonesia \\ m_hamid@uny.ac.id
}

\author{
Fathan Nurcahyo \\ Department of Physical Education, \\ Health, and Recreation \\ Universitas Negeri Yogyakarta \\ Yogyakarta, Indonesia \\ fathan_nurcahyo@uny.ac.id
}

\begin{abstract}
The purpose of this research was to understand teachers' experience in teaching inclusive physical education and to develop a theoretical model about how they include students with disability. This qualitative study used grounded theory involving 20 physical education specialists who taught in inclusive schools. Data were collected using deep-interviews and recorded in digital voice recorders. Verbatim transcribed were performed for further analysis. Researchers employed data analysis procedures recommended by grounded theory methodologists: open coding, axial coding, dan selective coding. Results shows that four themes including conceptualization of inclusive physical education, initial assessment, inclusive learning, and barriers to inclusive physical education. These themes will be presented to show the working theory of teaching inclusive physical education.
\end{abstract}

Keywords—inclusion, physical education, teaching

\section{INTRODUCTION}

One of the social justice issues in physical education is how it is socially inclusive. The concern covers aspects of physical education ranging from its curriculum to its pedagogy and learning. This social inclusion has been the concerns among researchers in the field of the sociological perspective of physical education since the past decades. Some of the researchers indicated that the exclusive nature of physical education is rooted in the close relationship between the subject and sport. More specifically, the curriculum of physical education is competitive in nature and oriented toward team sport [1]. Most countries experience this tendency, including Indonesia. Such curriculum structure is inherently exclusive which in turn prevents social inclusion in physical education.

This concern did not seem to go beyond the discourse in the academy until the policy of inclusive education had been established by the United Nation (UN) through Salamanca Statement [2]. Within the Indonesian policy context, the spirit of Salamanca Statement has been articulated in government regulation through Peraturan Menteri Pendidikan Nasional (Permendiknas) No. 70, year 2009 about inclusive education [3]. This Permendiknas becomes an important corner stone for new perspective about children with special needs including the pedagogical practice for those children in mainstream schools.

An example includes inclusive education as one of the main discourses among physical education teachers which have never been a central topic. Some of the professional development programs related to inclusive education are also offered for physical education teachers. In other words, it illustrates teachers' enthusiasm to develop their inclusive pedagogical practices.

Furthermore, we considered that it is interesting to study how teachers actually executed their pedagogical action of inclusive education. The literature in physical education has provided theoretical information about teachers' effort to include children with disability in their classrooms. From the theoretical perspectives, inclusive physical education consists of four areas: knowledge and curriculum related to ability and disability, teachers' attitudes, teacher education, and new conceptualization about physical literacy from multiple perspective [4]. From the practical perspectives, Gordon (2011) stated that there should be new ideas about how teachers have organized physical education, grouped their students, used resources, made decision, and developed new understanding about appropriate and meaningful physical education [5]. Some of studies also specifically contribute to the literature about how teachers' acted their inclusive pedagogy (example: [6], [7], [8]).

Despite the availability of information about inclusive physical education in the literature, little is known about the process of including students with disability in physical education. Unfortunately, the contexts of these studies are outside Indonesia, yet some of these represent Indonesian physical education. Indonesian researchers have apparently begun to pay their attention to inclusive physical education. However, their studies tend to be broad and sporadic which have currently made difficult to draw a theoretical conclusion. Therefore, we would like to contribute to the Indonesian physical education literature by investigating teachers' experience about inclusive teaching and the process to include students with disability in physical education within the context of inclusive schools.

\section{THEORETICAL REVIEW}

The term inclusion has actually broader meaning, not only related to teaching students with special needs but also connected to area beyond education: society [9]. In other words, the idea of inclusion assumes equal opportunity in any aspects of social life by discounting gender, ethnic, socio-economic, ability/disability status. The current study used the concept of inclusion which refers to the effort of opening equality for people with disability. It focuses on individual with disability or having disability. Disability ranges from development and intellectual disabilities, physical disabilities, vision and hearing disabilities, behavior problems, learning disabilities, to genius potentials/special 
talents. Other term for children with disability includes children with special needs.

In addition, disability is also a discourse that is open for interpretation. There is no single definition of disability that universally agreed upon [10]. Historically, researchers have adopted medical model when defining disability [11]. In this model, disability is considered to be the limitation of bodily functions as a result of any abnormality of the physical aspects [12].

Then, researchers have switched their approach to what it is called social model. This model considers the existence of disability is rooted on the social construction. In other words, the society is responsible in making an individual disabled. One of important theorists about social model of disability stated that becoming an individual with disability means to have social limitations ranging from access to physical environment to social marginalization, unavailability of mobility infrastructure to the culture tending to question intellectual and social competencies [13]. The society becomes oppressive to those who are assumed to have disabilities. Therefore, the efforts to make more equal society could not disregard the social perspective of disability [14]. One way or another, the social model of disability has influence the concept of special education which is still based on types and complexity levels of disability [15].

Meanwhile, the most current perspective regards disability as an interaction between individual and the contextual factors of that individual which comprises of personal and environmental factors [16]. This model is called bio-psycho-social model (ICF Framework). It is important to note that disability is not always caused by medical diagnose or social malfunction, but it is rather an interaction of personal and environmental factors. So, all actions in disability issues, including education, do not only focus on individual disability but also on the environment that limits active participation of individuals' with disability. The researchers advocate the way to interpret disability using the perspective of ICF Framework because as the interactional model, this framework emphasizes on individual strength and modality, functional needs of people with disability [17]. This is aligned with the notion of inclusive education that emphasizes on students' ablity and needs within the friendly contexts through accommodation and modification of the learning environment [18]. Also, inclusive education has its significance within the broader policy and practice contexts, especially as a vehicle toward more justice society. The notion of inclusive education is oriented to contribute on the realization of society without discrimination and oppression. It can be called efforts that have social dimensions when giving the rights to children with disability together with other children to receive educational services that do not discriminate without disregarding the children's special characteristics. Education is a human right and therefore all children can be educated and have rights to get qualified education.

Furthermore, global movement on inclusive education is efforts to advocate and promote children with disability to receive educational service in mainstream schools. The movement assumes that school should provide children's needs to learn disregarding their conditions. This philosophical ground refers to these principals: (1) social justice and human rights, (2) all children are able to learn, (3) environment that are less limiting, (4) normalization, (5) age appropriateness [19]. As a result, the inclusive education movement impacts on the various backgrounds and students' physical conditions in schools [20].

In Indonesia, the ministry regulation Peraturan Menteri Pendidikan Nasional (Permendiknas) No. 70/2009 has legitimated lawfully to ensure students with disability receiving educational services equally with other students. Now, students with disability have more choice comparing years ago when their educational opportunity was only through Special Schools. This policy could be a good news for more just society. However, the inclusive education policy have put more pressure to teachers and administrators to facilitate disabled students' learning needs in mainstream schools [21], including the curriculum, pedagogical strategy, assessment, and school management [22].

The idea that teachers have important roles in the effectiveness of the inclusive policy implementation has also supported by literature. The success of inclusive education depends on at least teachers' attitude toward the implementation of inclusive education and their perceived competencies [23]. Consistently, a study by Elisa and Wrastari, for example, disclosed that teachers' positive or negative attitude toward inclusive education had been determined by several factors. Teachers tended to have positive attitude toward inclusive programs if students with disability had been considered ready to learn. Implicitly, this finding indicated that teachers tended to be not ready to provide the students' needs [24]. Meanwhile, teachers tended to be more open toward the notion of inclusive education when they dealt with students with mobility and sensory disorders in low category, but not for those with extreme behavior [25]. Some other determinant factors included teachers' backgrounds, knowledge, empathy, and teachers' needs to learn.

With regard to inclusive physical education, the researchers would like to briefly discuss the concept of physical education (PE). Essentially, PE is a formal teaching of knowledge and value through and about physical activity [26]. The purpose of PE is always contested. It changes overtime depending on who and what interests being carried out to give the meaning on PE [27] [28]. However, what might be relatively unchanged includes the purpose of PE to help students learn and develop knowledge repertoire and skills related to movement culture [29].

Before moving toward the inclusive PE, the notion of disability needs to be discussed. Unfortunately, how much physical educators emphasize the important of disability study in PE has still been a concern [30]. Furthermore, the democratic and just society should revisit critically about how ability is recognized, conceptualized, and socially configured, maintained, and embedded in the daily practice of physical education [31]. In other words, that statement implies how inclusive PE should be understood from a social perspective. So, PE could then potentially be ways by which social justice can be attained through education.

Some PE researchers have also focused their studies on inclusive education, despite they have not yet achieved conclusive theory. This is because the research on inclusive PE using social model perspective is still an agenda. The following paragraphs are examples:

Downs, Knowles, dan Fairclough conducted a survey study investigating teachers' perception toward physical activity of students with physical disabilities, especially their participation in the activity, covering: (1) students with disability enjoyed physical activity that was enjoyable and 
non-structured; (2) parents had important roles in supporting their students; and (3) close relationship between home and school [32]. In addition, Haegele dan Sutherland reviewed 13 qualitative studies on the perspective toward students with disability within the context of PE [33]. They concluded that teachers' positive attitude had become important key in ensuring meaningful learning experience. This meaningfulness can be accomplished by modification and accommodation during the learning process, creating disable-friendly PE, and providing choices of separated or inclusive learning environment.

Wang, Wang, dan Wen studied teachers' attitude toward students with disability in Shanghai. The results showed that teachers' interaction with their students with disability tended to be more verbal than physical. The efforts to improve teaching had also been done by the teachers by doing the activity in pairs. In addition, teachers also modified their instruction and equipment in order to maximized participation. Those studies provides an initial description about future research related to factors facilitating the participation of students with disability in physical activity and inclusive PE [34].

\section{III.METHODS}

\section{A. Research Approach}

This study was grounded theory research focusing on the participants' experience. We attempted to understand their experience in a way that we developed a theoretical framework as an abstract analytical scheme of the process [35]. In this study, the process was processes the teachers experienced in including students with disability in physical education. As a grounded theory study, the process of data collection was hand in hand with the data analysis. The researchers conducted these two methods simultaneously in order to compare and develop research sampling that was determined theoretically [36]. We terminated this process when a concept/theory/model have been fully developed.

\section{B. Participants}

The current research involved 20 physical education specialists who had been teaching in inclusive schools, ranging from elementary to high school levels. Criteria for recruiting participants have been established which included the minimum experience of teaching students with disability for at least 1 year. In addition, we also referred to the grounded theory procedure namely theoretical sampling when recruiting participants. This sampling technique guided us to sample participants based on our emerging theory.

\section{Settings}

This study took place in inclusive schools in Yogyakarta, Indonesia. The city is characterized by its strength in education. Commonly referred as city of education, Yogyakarta provide higher quality of teaching and learning in comparison to other city in the nation. The study was conducted from February to June 2018.

\section{Data Collection and Analysis}

We employed twi stages of interviews. First, we asked participants to identify steps in their inclusive process along with initial issues related to their efforts to include students with disability. In this stage, we already started the analysis by conducting open coding. The researchers were open to
Eny possibilities in the data. This stage was terminated when we found categories of information about studied phenomena. By structuring found categories as an initial model we entered the second stage. The second stage of interviews was conducted to form axial coding phase through which the researchers investigated the core experience, causal condition, strategy, and the impact toward the participants' teaching. The last stage was the selective coding through which the researchers wrote this report by connecting one category to another.

\section{IV.RESULTS}

The analysis in the first stage results in some categories that describe the participants' experience of including students with disabilities in their teaching. These include the construction of inclusive PE, type of disabilities; initial assessment, teaching process, and learning assessment.

\section{A. Conceptualization of Inclusive Physical Education}

The grounded theory analysis also looked for the construction of inclusive PE. The researchers believe that participants socially constructed the concept of inclusion through professional settings or participation in a community of practice. Since the discourse of inclusion have been circulated within the profession, their construction of inclusion showed that they have been socialized. Some teachers' conception included teaching students who had limitations, either physical or metal limitations. Putu said, "inclusion for me is how schools take the students' limitations or those who need special assistance. For example, those who have limited physical movement, vision, etc." Some of the teachers even demonstrated better understanding of inclusive PE involving a big picture of it. For example, Endo stated:

It can be said that inclusive physical education for me is part of overall education being served to students who have special needs. The terms special because in inclusive education students there are slow-learners etc so that they should get special physical education. That's my understanding.

That conception has been rooted in ideological ground for social justice. Such ideological ground seems to be common understanding since it might grow naturally from common moral standard.

\section{B. Initial Assessment}

Procedurally, teaching students with disability involves activity to assess the status of the students. In many developed countries, a disabled child entitled to educational supports in mainstream schools may need to provide an official document issued by medical professionals. This document states the disability status of a student. When the child enrolls in school, an initial assessment may be administered to assess her/his learning needs.

Such procedure is not a common practice in Indonesia. As a result, there was no a standardized way in getting to know the disability status. Analysis shows that most teachers "diagnosed" disabilities by themselves. At the outset, they were not aware if their disabled students were coming to their class. As the teaching process kicked off, they usually 
started to figure out that there might be students with special needs. Sajati said, "the first time I taught here, I didn't know there was a child with special needs in my class. I didn't know what that meant and what to do."

Some other teachers were aware of their incoming students with disability prior to their teaching. They got the information from the parents who stated about their child when they were enrolling their students. The lack of information about the status of disability has made the teachers misunderstood about their disabled students. For example Sajati told his experience:

I had a funny experience the first time I taught the class. After opening, I instructed a warming-up session by asking the students to jog. There was a student who was jogging by holding other student's hand. I shouted, 'hey, don't run hand in hand!' Then, there was a student who told me that that kid was blind. I didn't know what to do until my second experience when I substituted my colleague...I learned to teach these special kids by asking other teachers. I then started to know that we have to treat them specially, we have to be fully care. We treat them the same as other students without demanding them in physical activity.

Another common practice in Western countries is assessment conducted to inquire students needs. Rarely such assessment is practiced in Indonesia. This was also typical in our data. Some teachers experienced shocks when they figured out their students with special needs as their teaching began. Reno stated, "the first time I encountered the kid, I was shocked because I wasn't informed by the principal if I would have that disabled student."

Since each school district had different resource to support inclusive programs, there were only couple schools in this study that administered initial assessment. Special education specialists assigned by the local school districts run the assessment. Local university was also involved in the assessment process. Henfri said, "it was from the district, but sometimes also from UGM (Gadjah Mada University) also administered the test." Unfortunately, the district administrators did not inform the results of the assessment to the teachers. In turn, teachers' made a trial and error efforts to assess their students's needs. Henfri continued, "I observed the kids myself, why my teaching wasn't effective for this kid. There might be something. So, as long as I could see they weren't able or were unable to process lesson, or might be socially something. The brain is this, the social is that."

In some other schools, counseling office had responsibilities with taking care of the students with disability. However, the office job seemed to be merely informing that there were students with special needs. Not much about the specific status and condition of those students. Even, the information sometimes came late. Rohimin explained:

I firstly get the report from the counseling office and then I observe their behavior, how they walk etc. Then, when doing the activity I can definitely observe the disability...yeah I got the report from the counseling office but most of the time, it was too late. Sometimes, it was reported on the plenary meeting at the end of the semester, too late.

Teachers taught students with special need with limited information from professional assessment. Teachers seemed take this for granted and did not complain much if this lack of information might influence quality of their teaching. This was especially if it would not be able to ensure the quality of their teaching inclusiveness.

\section{Inclusive Learning}

As analysis in grounded theory, the presumption underlying the teachers' experience included the potential effects of lacking initial assessment to inclusive learning. Analysis shows sub-themes within the theme inclusive learning. These sub-themes include lesson plan, participation, modification and adaptation, motivation, and learning assessment. The following paragraphs are the description of the sub-themes.

Lesson plan. For many teachers, good teaching would begin from a well-planned lesson. All teachers in this study also planned their lessons. However, most of them did not specifically plan for individual learning for their students with disability. Analysis shows that it was difficult for the teachers to specifically plan the lesson for those with disability. Henfri said, "I plan my lesson the same to all of my students. It's hard for me (to plan for the disabled students). But I make it different on the level of the task." Some of them considered that they focused on the majority, which is the abled students. They did not want to be occupied only with students with special needs. Sajati, for example, stated that, "I don't focus to that. I made my lesson in general, for everyone. It's because the kid is only one, if I plan the lesson for this students, I would be too busy."

Few of the teachers understood that developing Individual Lesson Plan (ILP) was their responsibility. They also aware the important to plan a lesson specifically for students with special needs. However, these teacher would technically face difficulty in actually developing ILP. Most teachers considered to plan the same lesson plan for all students, but their actual teaching would be adjusted as needed. Bukber told his story:

It's not maximum yet. It's hard because I don't only teach PE here. I have another teaching job in other school. With regard to the administration, there was also barrier to plan ILP. I had students with disability and I also had ILP for them. It was like a lesson plan but for students with special needs. I had 20 students in my class and 5 of them had special needs. Now, I make the same lesson plan for everyone. They have the same standard of competencies, but each individual (with disabilities) can do the activity according to their ability. For me, my lesson plan is the same, but my actual teaching is different.

Data showed that teachers did not plan their lesson for their students with disability. The presumption might include that they did not have information about their students' disability status. Other premise is that the teachers' in this study did not have skills necessary to develop ILP.

Participation. The impact of lacking initial assessment and skills of teaching students with disability was teachers' 
pedagogical decision to at least encourage participation. Most participants stated that they focus on how to encourage participation of their disabled students in physical activity, no matter their condition. For these teachers, it was expected that their students with disability to show up in class. They did not have to do anything. As long as they were present, they could grade the students. This is typical in the data.

In addition, some other teachers wanted their students to enjoy the activity. They did not have to perform to a standard the teachers had been set. Yanri i said, "it's different if it's for a standard of performance. For their learning, I focus on their enjoyment." In a case when the students could not perform the activity at all, the teachers would ask them to observe the activity. Jony Hadman mentioned that his did not ask the students to do the activity if they could not do it. He said, "the students was on a wheel chair and when the activity was using legs, I let him just watch other students doing the activity."

Some other strategy to encourage participation was to pull out the students when they could not participate in physical activity. Teachers in this study would compensate their students with other activity they could perform with their limitation. For example, Farji had a student who had no hands. When it came to volley ball unit, he would pull the students and replace the activity. He said, "my student participated in all activity but the ones using hands. When my activity was volley ball, I would give him other activity." Furthermore, data analysis also found that teachers assigned other tasks if other activities were not available or possible. These tasks could be a written or reading assignments. Jony Hadman said, "when I had a student who could not do anything, I assigned them other tasks."

Modification and adaptation. In order to encourage students with disability in physical activity, teachers also modified and adapted their teaching. Despite most teachers modified their instruction, only few of them began from the lesson plan. Henshu said, "so I designed the lesson differently. My instructional methods is a little bit different adjusting their ability."

Although the teachers in this study did not specifically plan their lesson for their students with disability, their instruction were modified and adapted. Barry Dwi, for example, had modified the equipment. He said, " when I teach throw and catch and they couldn't do the task, I modified the equipment. Because if the ball is too small for them, they couldn't (do the tasks), so I use bigger balls so they could catch it."

Motivation. Pedagogical approach used by the teachers was to motivate students with disability. The teachers concerned that their students had disability and their condition might discourage participation. Putu said, "my feeling is how I could motivate those kids (with disability). They have special needs so I need to make sure that they don't feel unconfident."

In fact, their disabled students sometimes felt discouraged when the tasks were difficult to perform. The effectiveness of their motivating strategy has made them to keep on using this approach. Putu described that his disabled students felt unconfident for difficult tasks, but "I motivate them again and again. I always said "you can do it. When other students can do it, you can do it too'."

Learning assessment. One way to assure accountability is through leaning assessment. Most common practice of assessing students was performance-based assessment. Assessment for the students with disability was not an exception. All of the teachers participated in this study stated that they modified their assessment. Their modification included the adaptation of the assessment instruments or the standards. One of the participants said:

I have no difficulty in assessing students learning, because when doing it with students with disability I only need to know how good they are. If they don't do good, I will adjust my assessment. For example, if the competencies (standards) are 5, but they can only do 2, then those 2 would be the standard that I set. Even if they can do 2, I would simplify the assessment as long as they are assessed according to what they are able to do (Henshu).

\section{Barriers to Inclusive Physical Education}

Participants identified barriers to inclusive education included several aspects. Analysis showed that participants observed that their other students sometimes bullied their peers with disability. Despite the teachers stated that they could handle bullying in their class, it would hamper inclusive environment.

Other barrier that most participants had stated included equipment. More specifically, this was physical activity equipment specially designed for students with disability. In other words, the equipment needed was the ones modified or adapted for special needs. The unavailable equipment had made their inclusive teaching ineffective. Barry Dwi said, "my teaching has not been maximum yet, because my special students also need modified equipment. My school has no such equipment."

\section{Discussion}

The fourth themes represent the description of participants' experience about how they constructed inclusion and how they taught inclusive PE. Teachers socially constructed the notion of inclusion. Their construction is mainly from a practical perspective. In fact, the term inclusion has been introduced in Indonesia the last few years and from the lens of practitioners. The notion of inclusion in education seems to be socialized through professional development programs. In other words, the teachers' conceptualization mostly reflected their experience and seemed to be influential. However, their conception also represented some theoretical perspectives of inclusion. For example, their understanding of inclusion consisted of moral judgement. This judgement aligns with philosophical grounds of inclusive education as explored by Foreman [37].

Moral judgment illuminates pedagogical action. It also appeared in the data through which teachers interpreted the notion of inclusion and acted in their teaching. Grounded theory analysis yielded that what they acted as inclusive PE might be rooted in their conception of inclusion.

In addition, teaching inclusive PE should ideally begin with initial assessment. Many of the teachers in this study did not assess their students with disability. Those who had 
ones, the initial assessments were administered by district offices or nearby universities. Unfortunately, the result of the assessment were not socialized back to the teachers.

As a result, the teachers did not get information necessary to understand their students' needs. Then, they made decision to assess their special need students. Possibly, their assessment might not result in a more complete picture of the condition of the students and their specific needs.

When they were not well informed about their students, in turn, their teaching could be at risk of being ineffective. In fact, many of the teachers did not plan their teaching specifically designed for students with disability. They also set their teaching objective to the minimum, which was students' participation. It was prominent that when the teachers were not competent enough to teach special needs students, their pedagogical approach mostly included motivating students.

Apparently, most participants did not adapt and modified their teaching. Even, some of the teachers tended to not teach their special students when they did not know the specific condition of their students or the pedagogical approach for that condition. They pulled out their students and asked them to observe.

Finally, teachers in this study assessed their student learning, this included their students with disability. The assessment was adapted in terms of the standard called minimum passing criteria. More specifically, they set the minimum criteria bellow other students but not redesign their assessment itself. In other words, the students with disability had to perform the same as other as much as they can and then scored it. This score would be their standard.

\section{IV.CONCLUSION}

The current study provide a theoretical explanation about how teachers constructed their conception of inclusion and how it affected their teaching. The possible cause of their inclusive teaching was also from their competency to teach students with disability. As a result, the process of their inclusive PE might be defected as the fact that teachers were not well informed about the condition of the students.

The pedagogical approach was also minimum setting up to ask the students participation without further learning process. The teachers also motivated the students as other way to promote inclusive PE. Eventually, they assessed their students with disability through regular learning assessment but then lower the standard.

\section{REFERENCES}

1. H. Fitzgerald, \& D. Kirk, "Physical education as a normalizing practice: Is there a space for disability sport?," In Disability and Youth Sport, ed. H. Fitzgerald, hal: 91-105. London: Routledge. 2009.

2. UNESCO. Salamanca Statement and Framework for Action on Special Needs Education: United Nations Educational, Scientific, and Cultural Organization. 1994.

3. Permendiknas, Peraturan Menteri Pendidikan Nasional/No. 70/ Tahun 2009 tentang Pendidikan Inklusif. 2009.

4. W. Barber, Inclusive and accessible physical education: rethinking ability and disability in pre-service teacher education. Sport, Education, and Society, 2016, 12, hal. $1-13$.

5. B. Gordon, Inclusive physical educaton. New Zealand Physical Education, 44(2), hal. 20-21. 2011.

6. J. An, \& K. S. Meaney, Inclusion practice in elementary physical education: a social cognitive perspective. International Journal of Disability, Development, and Education, 62(2), hal. 143-157. 2015.

7. A. Smith, \& K. Green, Including pupils with special educational needs in secondary school physical education: a sociologicl analysis of teachers' views. British Journal of Sociology of Education, 2004, 25(5), 593-607.

8. H. Overton, A. Wrench, R. Garret, "Pedagogies for inclusion of junior primary students with disabilities in PE," Physical Education and Sport Pedagogy, 2016, 22(4), hal 413-414.

9. P. Foreman, Inclusion in Action. Melbourne: Thomson. 2008.

10. M. Palmer, \& D. Harley, "Models and measurement in disability: An international review," Health Policy and Planning, 27, 357-364. 2012.

11. B. Cox-White, \& S. F. Boxall, "Redefining disability: Maleficent, unjust, and inconsistent," Journal of medicine and Philosophy, 2009, 33, 558-576.

12. C. Barnes, \& G. Mercer, Disability. Cambridge: Polity Press. 2003.

13. M. Oliver, The Politics of Disablement. Basingstoke: MacMillan. 1990.

14. L. Barton, Disability, physical education and sport: Some critical observations and questions. In Hayley Fitzgerald (ed). Disability and Youth Sport. Oxon: Routledge. 2009.

15. L. Barton, Disability, physical education and sport: Some critical observations and questions. Dalam Hayley Fitzgerald (ed). Disability and Youth Sport. Oxon: Routledge. 2009.

16. WHO World Report on Disability: World Health Organization. 2011.

17. J. F. Smart, "The power of models of disability," Journal of Rehabilitation, 75, 3-11. 2009.

18. M. L. Wehmeyer, D. Lattin, \& M. Agran, "Achieving access to the general curriculum for students with mental retardation: A curriculum decision-making model," Education and Training in Mental Retardation and Developmental Disabilities, 36, 327-342. 2001.

19. P. Foreman, Inclusion in Action. Melbourne: Thomson. 2008.

20. R. Conway, Australian schools, policy and legistation in Perspective. In Mervyn Hyde, Lorelel Carpenter, Robert Conway. Diversity, Inclusion, and Engagement. Oxford: Oxford University Press. 2013.

21. R. Conway, Australian schools, policy and legistation in Perspective. Dalam Mervyn Hyde, Lorelel Carpenter, Robert Conway. Diversity, Inclusion, and Engagement. Oxford: Oxford University Pers. 2013.

22. Ishartiwi, "Implementasi pendidikan inklusif bagi anak berkebutuhan khusus dalam sistem persekolahan nasional," Jurnal Pendidikan Khusus, 2010, 6(1), 1-9.

23. A. Hodkinson, "Conceptions and misconceptions of inclusive education-one year on: A critical analysis of newly qualified teachers' knowledge and understanding of inclusion," Research in Education, 2006, 76, 43-55. 
24. S. Elisa, \& T. Wrastati, "Sikap guru terhadap pendidikan inklusi ditinjau dari faktor pembentuk sikap," Jurnal Psikologi Perkembangan dan Pendidikan, 2013. 2(1), 1-10.

25. J. Corbett, Supporting Inclusive Education: A Connective Pedagogy. London: Routledge Falmer. 2001.

26. T. Chandler, M. Cronin, \& W. Vamplew, Sport and Physical Education: The Key Concepts. London: Routledge. 2002.

27. K. Green, Understanding Physical Education. London: Sage Publications. 2008.

28. D. Kirk, Defining Physical Education: The Social Construction of a A School Subject in Postwar Britain. London: Routledge. 2012.

29. C. Setiawan, "Krisis identitas dan legitimasi dalam pendidikan jasmani," Jurnal Pendidikan Jasmani Indonesia, 2004, 1(1), 1-7.

30. L. Barton, Disability, physical education and sport: Some critical observations and questions. In Hayley Fitzgerald (ed). Disability and Youth Sport. Oxon: Routledge. 2009.

31. J. Evans, Making a Difference? Education and "Ability" in Physical Education. European Physical Education Review, 10(1): 95-108. 2004.

32. S. Downs, Z. Knowles, S. Fairclough, N. Heffernan, S. Whitehead, S. Halliwell, \& L. Boddy, "Exploring teachers' perceptions on physical activity engagement for children and young people with intellectual disabilities," European Journal of Special Needs Education, 2014, 29(3), 402-414. doi: 10.1080/08856257.2014.906979

33. J. Haegele, \& S. Sutherland, Perspectives of students with disabilities toward physical education: a qualitative inquiry review. Quest, 2015,67(3), 255-273, doi: 10.1080/00336297.2015.1050118

34. L. Wang, M. Wang, \& H. Wen, Teaching practice of physical education teachers for students with special needs: an application of the theory of planned behaviour. International Journal of Disability, Development and Education, 2015, 62(6), 590-607. doi: 10.1080/1034912X.2015.1077931

35. J. Creswell, Qualitative Inquiry and Research Design: Choosing Among Five Approach. Thousand Oaks, CA: Sage Publications. 2007.

36. T. A. Schwandt, The Sage Dictionary of Qualitative Inquiry. Thousand Oaks, CA: Sage Publications. 2007.

37. P. Foreman, Inclusion in Action. Melbourne: Thomson. 2008. 